\title{
PENYULUHAN KEWIRAUSAHAAN UNTUK MENINGKATKAN EKONOMI KELUARGA PADA WARGA TAMAN BACA KREATIF MEKARSARI
}

\author{
${ }^{1}$ Hastono, ${ }^{2}$ Janudin, ${ }^{3}$ Agus Supriatna, ${ }^{4}$ Fakung Rahman, \\ ${ }^{5}$ Yan Kristian Halomoan \\ Dosen Fakultas Ekonomi Universitas Pamulang \\ Email : dosen00340@unpam.ac.id
}

\begin{abstract}
ABSTRAK
Tujuan dari kegiatan pengabdian kepada masyarakat ini adalah untuk memberikan penyuluhan dan menggerakkan masyarakat agar berusaha membuka lapangan pekerjaannya sendiri dengan berwirausaha.

Metode pengabdian dengan mengadakan penyuluhan, sistem pemaparan secara klasikal, diskusi kelompok dan tanya jawab.

Dengan penyuluhan kewirausahaan untuk meningkatkan ekonomi masyarakat di kalangan Taman Belajar Kreatif Mekarsari diharapkan dapat memberikan wawasan kepada anggota yang nantinya dapat diterapkan oleh anggota dan ditularkan ke masyarakat luas.
\end{abstract}

\section{Kata Kunci: Wirausaha, Ekonomi Keluarga}

\section{PENDAHULUAN}

Permasalahan pemenuhan kebutuhan ekonomi mewarrnai kehidupan bermasyarakat. Daya saing yang sangat kompetitif dari masa ke masa menyebabkan tidak semua orang berusia produktif berkessempatan mendapatkan pekerjaan agar berpenghasilan untuk memenuhi kebutuhannya. Untuk masyarakat kalangan menengah ke atas dengan pendapatan yang besar, bukan menjadi masalah besar untuk pemenuhan kebutuhan, namun untuk masyarakat kalangan menengah ke bawah yang berpenghasilan sedikit atau mempunyai penghasilan tidak tetap, kondisi seperti sekarang ini dengan banyaknya kebutuhan yang harus dipenuhi, membuat hidup seakan sangat sulit. Begitu juga dengan masyarakat desa, yang notabene penghasilan keluarga dari hasil bertani atau berladang, pemenuhan kebutuhan ekonomi sehari-hari hanya mengandalkan hasil kebun atau ladangnya. Untuk memenuhi kebutuhan pokok sandang pangan dan papan masih tergolong sulit, apalagi untuk menuntut ilmu ke jenjang pendidikan yang lebih tinggi sangat berat, sehingga banyak ditemukan anak putus sekolah dan orang tua yang buta aksara. Kalau keadaan seperti ini terus berlanjut dan terus menambah angka anak putus sekolah maka masa depan mereka juga akan terancam.

Berdasarkan fenomena tersebut para pemuda Desa Mekarsari Kecamatan Rumpin Kabupaten Bogor menggangas berdirinya komunitas belajar yaitu Taman Belajar Kreatif Mekarsari (TBKM) untuk mewadahi anak-anak putus sekolah dan memberantas buta huruf bagi warga setempat. Taman Belajar Kreatif Mekarsari 
diprakarsai berdiri dengan segala keterbatasannya maka untuk kesekretarianatan atau proses kegiatan belajar pun sampai saat ini masih menumpang di Kantor Desa Mekarsari. Tenaga pengajar juga masih menggunakan tenaga relawan yang memiliki panggilan jiwa untuk berbagi pengetahuan dan pengalaman kepada masyarakat yang masih sangat membutuhkan perhatian dari pemerintahan setempat. Fasilitas yang serba terbatas tersebut menjadi salah satu factor kurang maksimalnya transfer pengetahuan atau pengalaman kepada warga Taman Belajar Kreatif Mekarsari, sehingga setelah menyelesaikan belajarnya, kurang mempunyai daya saing dengan warga masyarakat lainnya yang lulus dari Sekolah Menengah Atas ataupun Perguruan Tinggi. Lapangan kerja yang tersedia kurang bisa mewadahi untuk tamatan Taman Belajar Kreatif Mekarsari, dimana pada akhirnya hanya akan menambah angka pengangguran. Jika tamatan Taman Belajar Kreatif Mekarsari tidak berkesempatan untuk bersaing memperoleh pekerjaan yang layak, mereka harus dikondisikan untuk mampu mengatasi permasalahannya secara mandiri yaitu dengan cara berwirausaha untuk menciptakan lapangan pekerjaan dirinya sendiri dan orang lain sserta untuk memenuhi kebutuhan ekonomi keluarganya.

\section{METODE PELAKSANAAN KEGIATAN}

Metode pelaksanaan dalam kegiatan program pengabdian kepada masyarakat ini diawali dengan melakukan pendekatan kepada ketua Taman Belajar Kreatif Mekarsari. Survey awal yang dilakukan oleh tim pengusul untuk menjajaki dan mengetahui permasalahan yang ada di internal TBKM dan masyarakat Desa Mekarsari Kecamatan Rumpin Kabupaten Bogor. Dari hasil survey awal melalui wawancara dengan ketua Taman Belajar Kreatif Mekarsari, disampaikan pada dasarnya keberadaan Taman Belajar Kreatif Mekarsari untuk membantu masyarakat Desa Mekarsari social dan ekonomi. Adapun metode pelaksanaan program kemitraan masyarakat sebagai berikut:

1. Tahap Pemilihan Lokasi Pengabdian

Tahap pemilihan lokasi pengabdian kepada masyarakat tentu harus mempertimbangkan banyak hal., salah satunya adalah kebutuhan masyarakat yang merupakan objek dari pengabdian.

2. Tahap Pengusulan

Setelah tim pengusul melakukan observasi awal dan sudah mengidentifikasi permasalahan pada objek pengabdian kepada masyarakat, maka dapat ditentukan temanya atau judulnya. Selanjutnya berdasarkan tema tersebut disusunlah proposal pengabdian kepada masyarakat yang diajukan melalui program Sintias.

3. Tahap Pengumpulan data

Pengumpulan data yaitu mengumpulkan data di lokasi pengabdian dengan melakukan konsultasi, observasi, wawancara, dan dokumentasi dengan menentukan strategi pengumpulan data yang dipandang tepat untuk menentukan tema atau fokus serta pendalaman data pada proses pengumpulan data berikutnya. 


\section{Tahap Pelaksanaan Pengabdian Kepada Masyarakat}

Tahap pelaksanaan pengabdian kepada masyarakat merupakan tahap pelaksanaan penyuluhan tentang kewirausahaan untuk meningkatkan perekonomian keluarga pada Taman Belajar Kreatif Mekarsari. Pada. tahap ini tim pengusul melakukan penyuluhan sesuai tema terkait, melakukan sharing pendapat, dan mengidentifikasi kebutuhan materi yang diinginkan dan penawaran program pengabdian kepada masyarakat berkelanjutan di masamasa yang akan datang.

5. Tahap Pelaporan Hasil Pengabdian

Pada tahan pelaporan hasil pengabdian kepada masyarakat ini merupakan laporan serangkaian kegiatan mulai dari surve pra pengabdian hingga pelaporan kegiatan.

6. Tahap Publikasi

Hasil atau laporan kegiatan pengabdian kepada masyarakat akan dipublikasikan sebagai luaran dari kegiatan pengabdian kepada masyarakat ini.

\section{HASIL DAN PEMBAHASAN}

Desa Mekarsari Kecamatan Rumpin Kabupaten Bogor masuk kedalam katagori Desa Madya, mata pencaharian masyarakat desa adalah bertani dan berladang taraf hidup masyarakat masih tergolong menengah ke bawah, jumlah lulusan perguruan tinggi masih tergolong sangat langka, masih banyak siswa putus sekolah dikarenakan ketiadaan biaya serta pengetahuan orang tua mengenai penting nya sekolah sangat minim. Melihat situasi kurangnya pendidikan di desa dan masih banyak ditemukan anak putus sekolah serta para orang tua yang buta aksara, maka para pemuda Desa Mekarsari, Kecamatan Rumpin, Kabupaten Bogor tergerak mendirikan Taman Belajar Kreatif Mekarsari (TBKM), suatu komunitas yang bertujuan membantu masyarakat desa mendapatkan pendidikan melaui jalur non formal. TBKM ini merupakan salah satu alternatif yang dipilih dan dijadikan sebagai ajang proses pemberdayaan masyaraka, maka akan banyak potensi yang dimiliki oleh masyarakat yang selama ini belum dikembangkan secara maksimal. TBKM diarahkan untuk dapat mengembangkan potensi-potensi tersebut menjadi bermanfaat bagi kehidupannya. Agar mampu mengembangkan potensi-potensi tersebut, maka diupayakan kegiatan pembelajaran yang diselenggarakan di TBKM bervariasi sesuai dengan kebutuhan masyarakat. Berdasarkan fenomena tersebut para pemuda Desa Mekarsari Kecamatan Rumpin Kabupaten Bogor menggangas berdirinya komunitas belajar yaitu Taman Belajar Kreatif Mekarsari (TBKM) untuk mewadahi anak-anak putus sekolah dan memberantas buta huruf bagi warga setempat. Taman Belajar Kreatif Mekarsari diprakarsai berdiri dengan segala keterbatasannya maka untuk kesekretarianatan atau proses kegiatan belajar pun sampai saat ini masih menumpang di Kantor Desa Mekarsari. Tenaga pengajar juga masih menggunakan tenaga relawan yang memiliki panggilan jiwa untuk berbagi pengetahuan dan pengalaman kepada masyarakat yang masih sangat membutuhkan perhatian dari pemerintahan setempat. Semuanya masih serba 
terbatas mulai dari tempat belajar, sarana dan prasarana belajar, sumber daya manusia dan fasilitas lainnya.

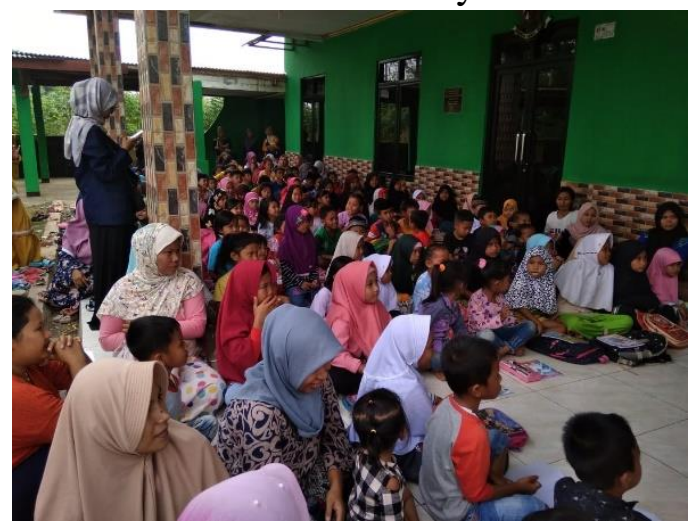

Ekonomi keluarga dapat diartikan keadaan atau kedudukan (orang, badan) dalam berhubungan dengan masyarakat di sekelilingnya. Ekonomi berarti urusan keuangan rumah tangga (organisasi, lembaga) di masyarakat. Ekonomi keluarga juga menentukan tingkat kemampuan pemenuhan kebutuhan anggota keluaga, secara berkelanjutan yang mencerminkan peningkatan ekonomi keluarga (Gunartin, 2019). Untuk sampai pada posisi aman dalam ekonomi keluarga perlu upaya terus meningkatkan pendapatan dan mampu memanfaatkan seefisien mungkin dalam pemenuhan kebutuhan sehingga masih ada kelebihan yang dapat ditabung atau diinvestasikan secara berkelanjutan. Dalam kurun waktu yang lama apabila diakumulasikan maka akan dapat terkumpul dalam jumlah yang besar yang merupakan kekayaan pribadi.

Dalam masyarakat ekonomi keluarga diklasifikasikan menjadi kalangan ekonomi keluarga mampu, kalangan ekonomi keluarga menengah dan kalangan ekonomi keluarga kurang mampu.

\section{Ekonomi Keluarga Mampu}

Keluarga mampu atau lebih sering dibilang lapisan atas pada masyarakat tertentu juga diistilahkan lapisan elit. Dan biasanya lapisan golongan atas merupakan golongan kecil dalam masyarakat dan juga mengendalikan masyarakat. Kekayaan dapat dijumpai dalam masyarakat ini dan di anggap sebagai hal yang wajar

2. Ekonomi Keluarga Menengah

Status golongan ini dapat hidup di tengah-tengah masyarakat yang bermacam-macam. Golongan ini seseeorang tidak berlebihan di dalam membelanjakan hartanya juga tidak kekurangan di dalam mencukupi kebutuan keluarganya. Status mereka dapat berkomunikasi baik dengan status di atasnya maupun status di bawahnya. Pada tingkatan ini jarang ditemui masalah yang menonjol dalam berkomunikasi dengan status lainnya.

3. Ekonomi Keluarga Kurang Mampu

Status yang kebanyakan melekat pada masyarakat pedesaan atau pemukiman masyarakat yang tertinggal dan berdampak pada kehidupan seharihari terutama untuk pendidikan dan mencukupi kebutuhannya.

Seseorang yang berani secara mandiri memproses, melakukan identifikasi serta mengembangkan dengan menggerakkan semua sumber daya yang dimiliki merupakan pengerrtian dari wirausaha . Juga dapat diartikan bahwa wirausaha merupakan proses mengidentifikasi, mengembangkan dan membawa tujuan ke dalam kehidupan (Kasali, 2008) 
Taman Belajar Kreatif (TBK) secara badan hukum memang merupakan pusat belajar yang berada ditengah-tengah masyarakat untuk mewadahi masyarakat yang terkendala menyelesaikan pendidikan di lingkungan pendidikan formal. Sebagian masyarakat awam masih belum paham dengan baik tentang keberadaan TBK sehingga kurang begitu peduli untuk tumbuh kembangnya TBM. Karena TBM ini berdiri atas dasar kebutuhan masyarakat dari berbagai latar belakang sosial, ekonomi dan pendidikian, harusnya mendapatkan dukungan penuh dari masyarakat sehingga fungsi dari TBM sebagai pusat belajar masyarakat tidak saja sebagai penyetaraan tetapi mampu sebagai wadah untuk pemberdayaan masyarakat dan menumbuhkan kemandirian wirausaha.

\section{KESIMPULAN DAN SARAN}

Dengan penyuluhan tentang kewirausahaan untuk meningkatkan ekonomi masyarakat di kalangan Taman Belajar Kreatif Mekarsari diharapkan dapat memberikan wawasan kepada anggota yang nantinya dapat diterapkan oleh anggota dan ditularkan ke masyarakat luas.

Solusi untuk memberikan penyuluhan kewirausahaan untuk meningkatkan perekonomi keluarga ini sebenarnya juga masih belum cukup harus dilakukan pelatihan dan pembinaan secara berkelanjutan sebagai pembekalan berwirausaha, masih banyak solusi yang bisa diberikan untuk peningkatan perekonomi keluarga. Secara berkelanjutan tim pengusul akan terus melakukan binaan untuk berbagi pengetahuan dan pengalaman dalam kemasan pengabdian kepada masyarakat. Tim pengusul pengabdian kepada masyarakat akan terus berupaya meningkatkan produktivitas masyarakat dengan menyesuaikan potensi masyarakat setempat.

\section{DAFTAR PUSTAKA}

Gunartin, Soffi, Feb Amni, Pusat Kegiatan Belajar Masyarakat Sebagai Tempat Alternatif Menumbuhkan Kemandirian Wirausaha Warga Belajar (Studi pada PKBM Insan Karya Pamulang Tangerang Selatan, Jurnal PEKOBIS Volume 3 Nomor 2 Oktober 2018

Kasali, 2008. Wirausaha Muda Mandiri. Gramedia Pustaka Utama Jakarta.

Sunasi, D., Kusjono, G., \& Nuryana, I. (2019). Pelatihan Manajemen Penguasaan Kelas Dan Pembuatan Bahan Ajar Bagi Tenaga Pengajar Sukarela Taman Belajar Kreatif Mekarsari. Jurnal Pengabdian Dharma Laksana, 2(1), 4144.

Sunarsi, D. (2018). Analisis Motivasi Kerja Tenaga Pendidik Sukarela Pada Pusat Kegiatan Belajar Masyarakat (PKBM) Bimasda Kota Tangerang Selatan. Kreatif: Jurnal Ilmiah Prodi Manajemen Universitas Pamulang, 6(2), 5365 . 